\title{
Emerging Economies, Trade Policy, and Macroeconomic Shocks
}

\author{
Chad P. Bown ${ }^{+}$ \\ The World Bank and CEPR
}

\author{
Meredith A. Crowley \\ University of Cambridge
}

This version: March 2014

\begin{abstract}
This paper estimates the impact of aggregate fluctuations on the time-varying trade policies of thirteen major emerging economies over 1989-2010; by 2010, these WTO member countries collectively accounted for 21 percent of world merchandise imports and 22 percent of world GDP. We examine determinants of carefully constructed, bilateral measures of new import restrictions on products arising through the temporary trade barrier (TTB) policies of antidumping, safeguards, and countervailing duties. We find evidence of a counter-cyclical relationship between macroeconomic shocks and new TTB import restrictions as well as an important role for fluctuations in bilateral real exchange rates. Furthermore, the trade policy responsiveness coinciding with WTO establishment in 1995 suggests a significant change relative to the pre-WTO period; i.e., new import restrictions became more counter-cyclical and sensitive to real exchange rate shocks over time. Finally, we also present results that explicitly address changes to the institutional environment facing these emerging economies as they joined the WTO and adopted disciplines to restrain their application of other trade policies such as applied import tariffs.
\end{abstract}

JEL No. F13

Keywords: antidumping, safeguards, temporary trade barriers, emerging economies, tariffs, WTO, business cycles, exchange rates

\footnotetext{
${ }^{\dagger}$ Bown: Development Research Group, Trade and International Integration (DECTI); The World Bank, $1818 \mathrm{H}$ Street, NW, MSN MC3-303, Washington, DC 20433 USA. tel: +1.202.473.9588, fax: +1.202.522.1159, email: cbown@worldbank.org, web: https://sites.google.com/site/chadpbown/. [Sector Board: EPOL.]

${ }^{\ddagger}$ Crowley: Faculty of Economics, University of Cambridge, Austin Robinson Building, Sidgwick Avenue, Cambridge, CB3 9DD United Kingdom. tel: +44.1223.335261, email: crowley.meredith@gmail.com, web: http://meredithcrowley.weebly.com/.

Thanks for useful discussions to Robert Staiger, Douglas Irwin, Giovanni Maggi, Shang-Jin Wei, Aaditya Mattoo, Rachel McCulloch, Kyle Handley, Russell Hillberry, David Tarr, Daniel Dias, participants at the Tsinghua-Columbia Conference in Beijing, the EIIT Conference at UC-Santa Cruz, and seminars at Yale, Dartmouth, Michigan, Syracuse, Georgia Tech, FIU, the World Bank, and Chicago Fed. Aksel Erbahar, Carys Golesworthy, Chrissy Ostrowski, and Jake Fabina provided outstanding research assistance. Any opinions expressed in this paper are the authors' and should not be attributed to the World Bank. All remaining errors are our own.
} 


\section{Introduction}

Why do countries sign trade agreements that restrict their use of import tariffs? A series of theoretical models dating back to Staiger and Tabellini (1987) and, more recently, Maggi and Rodriguez-Clare $(1998,2007)$, suggest that a trade agreement can serve as a commitment device for governments that seek to enact a more liberal trade regime but which are plagued by timeconsistency problems. This theory is thought to be particularly relevant for many emerging economies, as these countries may not be sufficiently "large" in world markets so as to motivate use of trade agreements for the standard terms-of-trade reasons (Bagwell and Staiger, 1999). ${ }^{1}$

Despite the strong theoretical predictions of the commitment literature, there is only limited empirical evidence on the explicit channels through which trade agreements facilitate different economic outcomes, let alone changes in policymaking behavior that might be associated with trade agreement commitments. Tang and Wei (2009) provide indirect support by using a difference-indifference approach to examine how trade and other reform commitments impact GDP growth and the aggregate investment to GDP ratio. Their finding that countries required to undertake more serious trade reform efforts in order to join the WTO enjoyed better economic outcomes is consistent with evidence that the WTO can help the time-consistency problem in tariff setting. Similarly, Subramanian and Wei (2007) have identified certain channels through which active participation in the multilateral trading regime has promoted trade growth. Their results challenge earlier studies such as Rose (2004) which finds little increased trade growth associated with the GATT/WTO system on average across countries.

The purpose of this paper is to empirically investigate how a number of major emerging economies conducted their trade policy over 1989-2010 and, in particular, how the conduct of their trade policy changed by taking on commitments when joining the WTO in 1995. First, as we describe in further detail below, these economies exhibit variation in trade policy commitments across at least two important dimensions - (1) there is considerable cross-country variation in the share of products with any maximum tariff rate commitment, and (2) there is substantial cross-country variation in the simple average tariff rate over all products with any established maximum binding rate. Second, we describe how these economies have partially unwound their tariff commitments by resorting to a set

\footnotetext{
${ }^{1}$ Such countries may seek trade agreements for other reasons if, because they are "small" in world markets, they are not necessarily seeking partners against which to reciprocally neutralize the price impact of tariff cuts and coordinate policy changes so as to move jointly from the terms-of-trade driven prisoner's dilemma outcome.
} 
of potentially WTO-consistent policies that permit the imposition of "temporary" trade barriers if specific economic and legal criteria are met. Our results paint a complex picture of the nature of trade policy commitments that emerging economies have taken on during this period under the WTO. On one hand, the use of temporary trade barrier policies of antidumping, safeguards, and countervailing duties may signal evidence of these countries' commitment to the WTO's principles of transparency and stability in trade policy determination. On the other hand, the increasing use of such import restrictions may also signal a step back from the more fully liberal regime that they promised to employ by lowering and binding their more general applied most-favored-nation (MFN) import tariffs.

Our particular approach is to examine the responsiveness of time-varying import protection to macroeconomic shocks for thirteen major emerging economies covering 1989-2010. We specifically investigate the imposition of new import protection through temporary trade barriers (TTBs) by constructing measures of import protection built up from disaggregated, product-level data. The emerging economies in our analysis are increasingly important contributors to the global economy; cumulatively by 2010, they combined to account for 21 percent of world merchandise imports and 22 percent of world GDP. ${ }^{2}$ Furthermore, the economic relevance of emerging economies' application of TTBs in particular is increasingly apparent. Bown (2012a) documents that for the major Group of 20 (G20) emerging economies, the collective share of import products subject to TTB import restrictions increased more than 50 percent between 2007 and 2010 alone. ${ }^{3}$ Finally, Bown (2011) finds that many of the G20 emerging economies also in our sample - including Argentina, Brazil, China, India, Indonesia, Mexico, South Africa, and Turkey - have used TTBs over 1990-2009 in ways that rival the intensity (product coverage) and frequency (number of policies imposed and removed) of high income economies like the United States and European Union. ${ }^{4}$

\footnotetext{
${ }^{2}$ As we explain in more detail below, our sample only includes major users of these TTB policies of import protection. Our econometric approach exploits country-level fixed effects which themselves would capture nonuse by the countries omitted from our analysis if included.

${ }^{3}$ See Bown (2012a, Table A1a) which updates the data originally presented as Table 3 of Bown (2011) through 2011. Note that Mexico, Russia and Saudi Arabia are omitted from the G20 emerging economy sample for these statistics, though Mexico is included in the estimation sample described below.

${ }^{4} \mathrm{~A}$ major difference, of course, is that the US and EU have a much longer history of accepting external enforcement of their trade policy commitments through the multilateral institutions, more binding trade policy commitments, and an experience with TTBs that dates back to at least the 1960s. The extensive research literature examining determinants of TTBs by high income economies is surveyed by Blonigen and Prusa (2003).
} 
We begin our econometric investigation by documenting a general counter-cyclical relationship between macroeconomic growth and import protection for the period covering the inception of the WTO in 1995 through 2010. For these emerging economies, a decrease in domestic real GDP growth or an increase in the domestic unemployment rate leads to significantly more imported products subject to TTBs in the subsequent year. Furthermore, real appreciation of the bilateral exchange rate relative to a trading partner is also associated with subsequently more import restrictions, as is weak foreign GDP growth in a trading partner. The relationships for these emerging economies during this particular period are similar to those found in a sample of five high-income economies over the longer period of 1989-2010 (Bown and Crowley, 2013a). ${ }^{5}$ Nevertheless, these new results are particularly important in light of recent evidence from Rose (2013), which examines a number of other trade policy instruments (and a longer time series of data) and concludes that there has been a secular decline in the sensitivity of import protection across countries. ${ }^{6}$ Rose's paper concludes that protectionism is no longer counter-cyclical; however, it does not specifically address the manner by which countries have engaged in inter-temporal substitution of trade policy away from applied import tariffs and toward instruments such as temporary trade barriers.

The second half of our empirical analysis explicitly addresses the potential for trade policy substitution over time across instruments, and it also examines the role played by tariff commitments under the WTO beginning in 1995. Our formal approach is to extend our data sample back to 1989 and to compare how these emerging economies conducted their trade policies under both the GATT (pre-1995) and WTO (1995 onwards) regimes. We provide evidence that the increased responsiveness of TTBs to macroeconomic fluctuations after 1995 represents a significant departure from how the major emerging economies used these trade policy instruments before 1995, suggesting an

\footnotetext{
${ }^{5}$ Bown and Crowley (2013a) examines data from the United States, European Union, Australia, Canada, and South Korea and is most closely related to a prior literature examining antidumping use by the United States and a handful of other high income countries on data from the 1980s and 1990s, including Knetter and Prusa (2003) and Feinberg (1989). One substantial difference is that while the current paper relies on the best available data across countries at the annual frequency, Bown and Crowley (2013a) was able to access data for high-income economies at the quarterly frequency. Another related paper is Crowley (2011), which is the first that we are aware of that highlights the channel of policy-imposing economies using country-specific bilateral import restrictions against trading partners that were experiencing negative growth shocks at home. Bown (2008) presents an approach that considers macroeconomic and industry-level determinants of antidumping for a number of the emerging economies in our sample for the period 1995-2002.

${ }^{6}$ The evolving literature on import protection taking place during the Great Recession also includes Bussiere, Perez-Barreiro, Straub and Taglioni (2010), Kee, Neagu and Nicita (2013), Gawande, Hoekman, and Cue (2014), and Davis and Pelc (2012), in addition to Bown (2011).
} 
institutional impact of the WTO. These results are robust to controlling for inter-temporal changes to WTO discipline over a country's other trade policies, such as its applied MFN tariffs.

In particular, we find that emerging economies implement TTB import protection during periods when a greater number of their imported products have become subject to the WTO disciplines that constrain a country's ability to raise applied MFN tariff rates. ${ }^{7}$ Our empirical approach directly addresses the issue that emerging economy aggregate-level demand for TTBs might vary across countries and over time due to variation in the stringency of WTO discipline over their other trade policies. As we further describe below, this arises due to two important institutional differences between how high-income and emerging economies conducted their trade policy during this period. First consider applied import tariff levels. For any given year, most of the emerging economies in our sample had applied import tariffs that made them much less open to trade relative to high income economies - e.g., those studied in Bown and Crowley (2013a). Furthermore, many of these emerging economies also had lower applied tariffs in 2010 than at the beginning of the period. Second, emerging economies differ from high income countries in that most retained some freedom to make WTO-consistent increases to their applied MFN import tariffs. Our approach specifically controls for the time variation within and across countries in the extent to which WTO disciplines constrain an economy's discretion to change its applied tariff rates.

This evidence in particular, regarding the empirical relevance of the WTO and the role of economic incentives for trade policy formation in emerging economies, is consistent with results from an evolving literature that examines the extent to which economic incentives and economic shocks affect the trade policies of emerging economies, especially in light of these countries' increasing engagement in the rules-based multilateral trading system. Recent evidence from emerging economies documenting the importance of economic determinants of trade policy formation pushes beyond traditionally political motives such as income redistribution or lobbying. Broda, Limão, and Weinstein (2008), for example, find that economic incentives affect non-cooperative tariff levels prior to a country's WTO accession; their sample includes a number of emerging economies. Bagwell and Staiger (2011) similarly provide evidence that economic channels affect tariff reductions associated

\footnotetext{
${ }^{7}$ This cross-country evidence on the substitutability between applied MFN tariffs and use of TTBs is consistent with the micro-level results for India provided in Bown and Tovar (2011). That approach estimates a Grossman and Helpman (1994) model at the product level on repeated cross sections of data over 1990-2002 and concludes that many of India's cuts to its applied import tariffs resulting from its unilateral liberalization of the 1990s were subsequently unwound through the implementation of new TTBs such as antidumping and safeguards.
} 
with WTO accession negotiations. Our findings on TTBs also relate to a separate study on TTB use by the United States, in which Bown and Crowley (2013b) provide evidence that economic incentives at the sector level shape antidumping and safeguard use and thus US participation in cooperative, selfenforcing trade agreements such as the WTO, an idea first formalized theoretically by Bagwell and Staiger (1990).

The rest of the paper proceeds as follows. Section 2 summarizes the theoretical work regarding macroeconomic shocks and new import protection, and it characterizes the institutional environment facing emerging economies' trade policies under the WTO during 1995-2010. Section 3 introduces our empirical model and describes our panel dataset. Section 4 presents our baseline results regarding the relationship between macroeconomic fluctuations and new import restrictions for emerging economies under the WTO covering the years 1995-2010. In Section 5, we extend the data set back to 1989 where possible and compare emerging economy TTB use under the WTO relative to the prior GATT regime. Finally, Section 6 concludes.

\section{Theory, Institutional Environment, Empirical Model, and Data}

\subsection{Theory}

An extensive empirical literature documents evidence of counter-cyclical trade policy in industrialized economies. Nevertheless, there are relatively few theoretical contributions that explicitly model the channels through which such import protection arises. ${ }^{8}$ Political economy models face two empirical difficulties: first, changes in political parameters do not necessarily match the speed of economic fluctuations; second, there is little evidence that the government's preference for the welfare of import-competing sectors relative to consumers or export-oriented sectors rises during recessions.

Greater success in matching some of the stylized facts on time-varying trade restrictions comes from terms-of-trade-driven models of import protection. Consider first the approach of Bagwell and Staiger (1990); they present a dynamic, repeated-game model of the trade policy choices of two large countries that participate in a trade agreement. While global welfare is higher in such a framework when countries pursue a cooperative agreement that involves more liberal trade,

${ }^{8}$ See the extensive list of empirical research referenced in Bagwell and Staiger (2003), Rose (2013), and Bown and Crowley (2013a) for historical evidence. Irwin $(2011,2012)$ provides a recent analysis of the channels through which the shocks of the Great Depression are associated with the counter-cyclical increases in import protection of the 1930s. 
unexpected increases to trade volumes result in the incentive to increase tariffs in order to take advantage of static (one-period) welfare gains. In the face of trade volume shocks, cooperative trade policy in a self-enforcing trade agreement can therefore be characterized by periods in which trade barriers increase. In a related dynamic modeling framework, Bagwell and Staiger (2003) extend this basic approach by considering serially correlated shocks to growth in order to examine the relationship between other aggregate-level fluctuations and import protection. ${ }^{9}$ Counter-cyclical trade policy can arise in this environment because the terms-of-trade gain from a tariff increase which is a response to a transitory increase in import volume - can exceed the long-run cost of a trade war in a persistent recession during which future growth is expected to be slow. This model generates some of the key empirical predictions that we take to the data: new import barriers are expected to arise when aggregate growth is weak at home and aggregate growth is weak in an important foreign source of imports. ${ }^{10}$

\subsection{The WTO, discipline over applied tariffs, and emerging economy trade policy formation}

Our investigation of the cyclicality of import protection for emerging economies covers 1989-2010, which is an important period of change in the institutional environment for the conduct of trade policy. However, we begin our empirical analysis with the post-1995 period during which the establishment of the WTO instituted a common set of international rules governing the application of TTB policies. Nevertheless, even when focusing on this particular period, there are important crosscountry differences that likely influence emerging economy application of TTBs. First, a number of these economies undertook substantial trade liberalization and made economically meaningful cuts to their applied MFN import tariffs that were unilateral in the sense that they were not required by the WTO. Second, a number of countries accepted WTO discipline over their tariff and other trade policies for the first time. These disciplines define maximum tariff rates at the product level that

\footnotetext{
${ }^{9}$ More formally, the Bagwell and Staiger (2003) set-up assumes two countries that trade many products with the aggregate growth rate in each country modeled as the rate of new product entry. A Markov-switching process moves the international economy from phases of high growth to low growth. Importantly, in each phase, trade volumes are subject to transitory shocks so that temporarily high import volumes can be observed during recessionary periods.

${ }^{10}$ Crowley (2010) generates a similar prediction for the channel of weak trading partner growth by using a segmented markets model to show that antidumping import restrictions increase in response to weak foreign growth at the sector level.
} 
countries promise not to exceed except through the use of WTO-permissible exceptions such as temporary trade barrier policies of antidumping, safeguards, and countervailing duties. Nevertheless, the binding nature of these disciplines may vary both across countries and within countries over time during this period, and any examination of the macroeconomic forces driving emerging economy trade policy must control for such variation.

Consider the data on different trade policy instruments in Table 1. The scope of a country's tariff commitments under the WTO is most easily summarized through three measures - the share of the country's total imported products at the 6-digit Harmonized System (HS-06) level that have a maximum tariff rate commitment, i.e., that are "legally bound" (column 1), the simple average of the rates at which these tariffs are bound (column 2), and the difference between this legal binding tariff rate and the MFN applied tariff rate that the country implements over imports at the border (column 2 less column 3 or 4 ). Table 1 indicates that, for these three measures, there is substantial heterogeneity across the thirteen emerging economies in our sample. The differential between the average applied MFN tariff rates in 1995 and 2010 (columns 3 and 4) also indicates variation within some of these countries over time; for some emerging economies, average applied MFN tariffs in 2010 were higher than they were in 1995, while they are significantly lower in other economies.

Variation in applied tariff rates over the period suggests that an emerging economy's aggregate-level demand for tariffs under the WTO's TTB policies may change over time. When a country's tariff commitments bind or almost bind, i.e. for imported products with applied MFN tariff rates that are at or close to the WTO maximum binding rate, then the only WTO-permitted option to implement additional import protection for that product is through a TTB. Columns (5) and (6) report data from Bown (2012a) on the stock of temporary tariff barriers as a share of all imported products in 1995 and in 2010, respectively. A comparison of the data in these two columns indicates that there is considerable differentiation both across countries, as well as within countries over time, as to the economic importance of the import coverage of these TTB policies.

The complex interplay of broad trade liberalization commitments (as captured by WTO tariff bindings and applied tariff rates) and the potential unwinding of these commitments is summarized in the last three columns of Table 1 . These columns provide two cuts of the data from imported products at the HS-06 level. For these three columns, we define an HS-06 product as "under WTO discipline" if it has an applied import tariff that is within 10 percentage points of its legally binding rate at the WTO; i.e., these are products for which governments have relatively little scope to further 
increase their applied import tariffs. ${ }^{11}$ In other words, these are products with binding trade policy commitments.

Column (8) of Table 1 presents, by country, the average over 1995-2010 of the share of all new TTBs per year for products that are "under WTO discipline." For Argentina, 18.3 percent of the products over which it had used TTBs during 1995-2010 had applied tariffs that were within 10 percentage points of the legal binding. The first implication of this column is that there is considerable variation across countries. China, South Africa and India use TTBs in products for which their ability to raise applied rates is largely constrained. On the other hand, smaller economies, such as Colombia and Thailand, impose TTBs on products for which there is considerable scope - i.e., more than 10 percentage points for 100 percent of them - for applied tariff increases.

The last two columns examine the relationship between WTO discipline over applied tariff rates and new TTBs. For most countries in our sample, product categories that are under tight WTO discipline in year $t-1$ are more likely to face new TTBs in year t. For column (9) we construct the set of all TTBs that (1) did not have a TTB in place in year $t-1$ and that (2) faced a TTB in year $t$. We then calculate the fraction of these products that were under WTO discipline in year t. The reported statistic is the average of this fraction from 1995-2010. For column (10) we construct the set of products with (1) no TTB in place at time $t-1$ and (2) no TTB in place in year $t$. We then calculate the share of products in this set that were under WTO discipline in year $t$. The columns reveal that products that were under WTO discipline in year $t-1$ were more likely to face additional restrictions on imports in the following year. Again consider Argentina: a comparison of the data in columns (9) and (10) indicate that 20.2 percent of its products with new TTBs were constrained by WTO disciplines, whereas only 15.3 percent of TTB-unaffected products were constrained by WTO disciplines. With the exception of Turkey, this pattern is common across the G20 emerging economies; i.e., WTO disciplines which constrain other trade policy choices lead to disproportionately more new TTBs.

\footnotetext{
${ }^{11}$ For this exercise we consider 10 percentage points as opposed to, say, the applied tariff and binding rate being exactly equivalent; in the formal econometric analysis below we consider a number of different definitions. One motivation for using a slightly larger (10 percentage point) cutoff is given by the data on the size of TTBs applied as tariffs. Antidumping, for example, is frequently imposed as a new import duty at ad valorem rates of over 100 percent (Bown, 2012b). In practical terms, it may be costly for a government to change any tariff rate and thus it may only be willing to do so through the applied tariff rate at the border if it can raise its tariff legally by, say, at least 10 percentage points; if not, it may choose a different policy instrument such as a TTB where the upper limit is less constrained.
} 
This latter information in Table 1, regarding the relationship between TTBs and WTO commitments over applied tariffs, motivates our construction of an aggregate, time-varying indicator that we employ in the second half of our formal econometric analysis described below. We seek to capture the binding nature of the WTO disciplines over a country's tariffs; we therefore begin by focusing on the share of a country's products with applied tariff rates equal to the WTO legal binding. We then take annual differences of this variable, and we expect a positive relationship between it and the aggregate-level demand for new import protection through TTBs; i.e., an increase in the share of the country's imported products that have applied tariffs equal to their legal binding rates would be associated with increased demand for TTBs the following year, ceteris paribus.

Figure 1 plots the year-to-year change in the share of each country's products with applied tariff rates equal to the WTO legal binding for the period 1996-2010. There is evidence of substantial variation - both over time and across countries - as to how constrained these emerging economies are by WTO disciplines over their applied import tariff policies. Argentina, India, Malaysia, Philippines and Thailand, for example, each have years for which there are major changes in the share of products falling under (or out of) WTO discipline. Given this anecdotal evidence of cross-country and inter-temporal variation in the binding nature of WTO disciplines over tariff policy for emerging economies, we explicitly control for the changing policy environment in our formal econometric analysis. We explore, for example, whether countries that are in a period with applied tariffs that are well below their legal bindings may be less likely to need to use TTB policies of import protection perhaps because they can raise their applied tariffs in response to shocks.

We conclude this section by noting that the environment characterized by Table 1 and Figure 1 for these emerging economies is quite distinct from that facing most of the high income economies studied in Bown and Crowley (2013a). For example, both the United States and European Union have bound 100 percent of their tariff lines under the WTO, and they have relatively low average bound tariff rates, at 3.6 percent and 4.2 percent, respectively. Furthermore, average applied MFN tariff rates for the US and EU are almost identical to their tariff bindings and they exhibit little time variation; i.e., these economies have little scope to raise applied MFN tariffs in response to economic shocks without violating WTO disciplines, and this is relatively time-invariant for 1995-2010. 


\section{Empirical model}

This section presents an empirical model of the aggregate-level determinants of import protection through the number of products that a government subjects to new temporary trade barrier investigations. The model relates the number of products under an antidumping, global safeguard, China safeguard, or countervailing duty investigation in a given year to the first lag of a number of macroeconomic variables. ${ }^{12}$ The general approach follows Bown and Crowley (2013a); we elaborate on the critical similarities and differences in more detail in the next section.

The dependent variable is the number of products imported from country $i$ against which the importing economy $j$ initiates a temporary trade barrier investigation in year $t$ that subsequently results in a new import restriction. This measure is a non-negative count and exhibits over-dispersion in that the variance of the number of investigations per time period exceeds the mean (see Table 2). We focus on products subject to investigations that ultimately result in the imposition of new import restrictions, though we do confirm the robustness of our results to other definitions. ${ }^{13}$ Unless expressly stated otherwise, in what follows we use temporary trade barriers and import protection interchangeably.

We formally model temporary trade barrier formation as generated by a negative binomial distribution (Hausman, Hall, and Griliches, 1984). In this model, the number of imported products under temporary trade barrier import protection, $y_{i j t}$, follows a Poisson process after conditioning on the explanatory variables, $x_{i j t}$, and unobserved heterogeneity, $u_{i j t}>0$. Specifically,

$$
y_{i j t} \mid x_{i j t}, u_{i j t} \sim \operatorname{Poisson}\left(u_{i j t} m\left(x_{i j t}, 6\right)\right), \text { where } u_{i j t} \sim \operatorname{gamma}(1, \alpha)
$$

Thus, the distribution of counts of products subject to new temporary trade barriers, $y_{i j t}$, given $x_{i j t}$ follows a negative binomial with conditional mean and variance

$$
E\left(y_{i j t} \mid x_{i j t}\right)=m\left(x_{i j t}, \beta\right)=\exp \left(x_{i j t} \theta\right) \text { and } \operatorname{Var}\left(y_{i j t} \mid x_{i j t}\right)=\exp \left(x_{i j t} \beta\right)+\left(\alpha \exp \left(x_{i j t} \theta\right)\right)^{2}
$$

\footnotetext{
12 Knetter and Prusa (2003) introduced the use of a negative binomial model to estimate the responsiveness of trade policy to aggregate growth in their study of antidumping filings by four industrialized economies.

13 The qualitative nature of our results is robust to a redefinition of the dependent variable to be products subject to TTB investigations, including even those do not ultimately conclude with the imposition of trade barriers. This may be important given the Staiger and Wolak (1994) evidence for the United States, for example, that even a mere TTB investigation can have trade-destroying effects.
} 
We use maximum likelihood to estimate the relationship between the number of products from country $i$ that economy $j$ subjects to policy investigations and import protection in year $t$ as a function of the lag (year $t-1$ ) of the percent change in the bilateral real exchange rate, domestic and trading partner $i$ real GDP growth, and bilateral import growth. The model is identified off inter-temporal variation in domestic real GDP growth and off inter-temporal and cross-sectional variation in bilateral real exchange rates, foreign trading partner real GDP growth, and bilateral import growth.

In interpreting the coefficient estimates from this model, we report incidence rate ratios (IRRs) for the explanatory variables. That is, we report the ratio of counts predicted by the model when the lag of an explanatory variable of interest is one unit above its mean value (and all other variables are at their means) to the counts predicted when all variables are at their means. To better quantify the results of our model, we also frequently present information on the percent change in the predicted counts of imported products becoming subject to new TTBs that our model generates in response to one standard deviation shocks to each of the explanatory variables of interest.

\subsection{Data and Variable Construction}

There are a number of similarities and differences in our data and modeling approach relative to our companion paper's (Bown and Crowley, 2013a) estimates on high income economies that require explicit clarification and justification.

Begin with the similarities. Like Bown and Crowley (2013a), we improve upon the prior literature through how we measure TTB import protection. We construct an annual time series of bilateral trade policy actions based on the universally-defined, 6-digit Harmonized System (HS-06) product level. The data for each policy-imposing economy begins either in 1989 or as soon as the country had TTB laws in place and available data on its use of TTBs (see Table 1, column 7). The data derive from extremely detailed trade policy information found in the World Bank's Temporary Trade Barriers Database (Bown, 2012b). Our measure of import protection is comprised of four arguably substitutable temporary trade barrier policies - antidumping, global safeguards, China-specific safeguards, and countervailing duties. Thus the dependent variable in our analysis is the count of HS06 imported products on which the government has agreed to initiate a new temporary trade barrier investigation against trading partner $i$ in year $t$ that results in import protection and against which there is not already an existing TTB in place. This count variable is carefully constructed for each 
policy-imposing country by trading partner and by year in a conservative way that does not allow for redundancy. ${ }^{14}$ In robustness checks, we also construct this variable using the antidumping policy alone and using all (non-redundant) TTB investigations, even those that did not result in the imposition of new import restrictions.

A second innovation relative to the prior literature is emphasis on a number of bilaterallydefined explanatory variables which enable us to focus on relationships between a policy-imposing economy and its key trading partners. ${ }^{15}$ This is empirically relevant for two reasons. First, the temporary trade barriers under study can be imposed bilaterally so as to discriminate across import sources. Second, two of the key macroeconomic determinants of import protection in our model trading partner i's real GDP growth and the bilateral real exchange rate - vary bilaterally. Our dataset with bilateral variation also allows us to examine if countries apply import protection against trading partners facing their own economic shocks.

There are three main differences in variable construction relative to the approach adopted in Bown and Crowley (2013a). The first distinction is this paper's use of data at the annual frequency, a limitation that the companion paper is able to overcome because data at the quarterly frequency is available for only a smaller set of high income economies. Second, due to data limitations for a number of emerging economies, we generally use domestic real GDP growth to capture the slowdown of the economy, whereas the companion paper used either the change in domestic unemployment rate or real GDP growth. The unemployment rate data series is not sufficiently available for all of the emerging economies in our analysis to use in the baseline estimates; however, we do employ it where

\footnotetext{
${ }^{14}$ At any point in time in the sample period under the Harmonized System, there are roughly 5000 HS-06 imported products that could be imported from any particular trading partner. In terms of policy, governments impose these import restrictions at the 8- or 10-digit product level; unfortunately the HS-06 level is the most finely disaggregated level of data that is comparable across countries. First, so as to avoid double counting in cases in which new import protection at the 8-digit level falls into the same HS-06 category as a previously imposed measure, we do not include such products. Second, for the more expansive import protection measure covering all four policies, we also do not include products that were subject to a simultaneous or previously imposed TTB under a different policy. This phenomenon is particularly relevant as most countervailing duties are imposed simultaneously with antidumping duties on the same products. For a discussion, see Bown (2011).

${ }^{15}$ The Appendix lists the trading partners $i$ for each of our thirteen policy-imposing economies. We condition on major trading partners affected by TTBs given that our estimation includes country fixed effects that would otherwise explain non-application against countries that a particular imposing country never targeted. Nevertheless, the trading partners included in our dataset are generally found to be the source of more than two thirds of the policy-imposing economies' non-oil imports during the sample period, ranging from 65 percent for Thailand to 91 percent for Mexico. The Philippines is a notable outlier for which the available bilateral trading partners comprise only 38 percent of non-oil imports.
} 
available in our sensitivity analysis. As we document below, here we also find strong results when we are able to utilize the unemployment measure.

Third, and most importantly, the current paper also ultimately directly confronts the changing institutional and policy environment in which emerging economies employ TTBs during 1989-2010. As noted above, when we turn to examine the channels through which the WTO may be impacting TTB import protection, one of our key determinants is defined as the share of the country's HS-06 tariff lines that are equal to its WTO legal binding, and we look at year-to-year changes in this variable. We expect a positive relationship between this determinant and the count of products subject to new TTBs; i.e., if the share of products with applied MFN tariffs equal to the WTO maximum binding tariff increases, then we expect aggregate-level demand for TTBs to increase, ceteris paribus. ${ }^{16}$ Note that while there is inter-temporal variation in this determinant, because both MFN applied rates and WTO tariff commitments are applied equally to all trading partners, there is no cross- trading partner variation within a given policy-imposing economy. Furthermore, the country-specific indicator variable that we employ in the estimation captures any time-invariant differences in the restrictiveness of WTO commitments across countries. ${ }^{17}$ In addition, when we compare trade policy formation under the WTO to policy formation during the GATT years, we interact indicator variables for the relevant trade agreement regime with the other determinants of interest.

Finally, we estimate the negative binomial regression model of the contemporaneous (time $t=0$ ) count of imported products subject to new import protection, as a function of the value that these explanatory variables take on one year earlier, i.e., at time $t=-1$. Table 2 presents summary statistics for the data used in the empirical analysis, and the Appendix provides more information on the underlying sources of the data.

\footnotetext{
${ }^{16}$ Indeed, Bown and Crowley (2013a) consider the role of WTO disciplines for high income economies. While the estimated IRRs from that paper are in line with theoretical expectations, they are not precisely estimated. One explanation for the imprecision is the lack of inter-temporal and cross-sectional variation in WTO disciplines across the five high income economies during this sample period.

${ }^{17}$ To clarify, we might also expect the level of a country's WTO disciplines to impact TTB determination. I.e., policy-imposing countries that have bound less than 100 percent of their tariffs (see column 1 of Table 1) might be less likely to use TTBs than others because there is no WTO discipline over products with unbound tariffs. However, because there is no inter-temporal variation in the share of a country's MFN tariffs that are bound during the WTO period, any level differences are captured by the importing country indicator variables.
} 


\section{Baseline Results for 1995-2010}

Table 3 presents results from our empirical model of temporary trade barriers (TTBs) for the full sample of thirteen emerging economies between 1995 and 2010. We begin with this period because a common set of rules governing TTB import restrictions came into force with the WTO establishment in 1995. We consider pre-1995 data in the next Section below.

As is common practice for negative binomial regression models, we report estimates for incidence rate ratios (IRRs). An estimated IRR with a value that is statistically greater than 1 is evidence of a positive effect of the explanatory variable of interest, whereas a value statistically less than 1 is evidence of a negative effect. The table also reports $t$-statistics for whether the estimated IRR is statistically different from 1. Each explanatory variable - the bilateral real exchange rate, domestic real GDP growth, foreign real GDP growth, and bilateral import growth - is lagged one year. Our basic specifications include bilateral fixed effects for each importing-exporting economy pair to control for time-invariant, trading-partner-pair-specific heterogeneity in the application of new import protection through temporary trade barrier policies. We also include a time trend in each specification. Finally, while the focus of our analysis is on use of all TTBs - antidumping, safeguards, and countervailing duties - we also include a specification that examines only the antidumping policy. Historically, antidumping has been the most frequently applied TTB in use by high income and emerging economies.

The first column of Table 3 indicates the results on the three macroeconomic variables - the percent change in the bilateral real exchange rate, domestic real GDP growth, and foreign real GDP growth - are similar to what has been observed for high income economies. The IRR of 1.01 in the first row indicates an appreciation of the bilateral real exchange rate is associated with more TTBs against that particular partner in the following year. Import protection also reacts counter-cyclically to real GDP growth; a decline in both domestic and trading partner GDP growth is associated with more temporary trade barriers. In particular, the IRR of 0.97 on growth in trading partner $i$ means that import restrictions are targeted against trading partners experiencing relatively weaker growth in the previous period. The IRR on bilateral import growth is just slightly greater than one (though it rounds down to 1.00) and is imprecisely estimated, indicating that changes in import growth have no effect on the number of temporary trade barriers. Finally, the IRR on the time trend is 1.02 , indicating that import protection under these instruments is trending upward on average for this sample of countries over this period, though this is not statistically significant. 
Before moving on to the other specifications in Table 3, we turn to an interpretation of the economic magnitudes of the results. Since understanding the size of effects is difficult when focusing on IRRs, Figure 2 presents additional information on the economic significance of the determinants of temporary new import protection. We begin by computing the model's predicted estimates of temporary trade barriers for all observations in our estimation sample. We then introduce a one standard deviation shock to each variable of interest at time $t-1$ and predict the count of temporary trade barriers at time $t$. Figure 2 illustrates the percent change in the mean number of HS-06 products subject to TTBs in response to the specified shock.

Overall, Figure 2 indicates that the model predicts sizeable increases in the number of products subject to TTBs in response to the various macroeconomic shocks. Results from the baseline specification are quantified by the horizontally striped bars. Beginning with the left side of the figure, the first four bars quantify how a one standard deviation appreciation of the bilateral real exchange rate at $t-1$ impacts the number of products subject to new TTBs at time $t$. A one standard deviation appreciation (approximately 18 percent in our sample) increases the number of new TTBs by 18 percent. The second group of four bars quantifies the impact of a domestic economic slowdown. A one standard deviation decrease in domestic real GDP growth (4.3 percent) leads to a 32 percent increase in the number of products subject to new import protection. Turning to the third group of bars in Figure 2, we see that weakness in a bilateral trading partner is also important; a one standard deviation decrease in trading partner i's real GDP growth (4.2 percent) is associated with a 16 percent increase in the number of temporary trade barriers it faces in the following year. Lastly, the fourth group of bars quantifies the impact of bilateral import growth. Although imprecisely estimated and not statistically different from one, the exact estimate on the IRR of 1.0006 implies that a one standard deviation in import growth would lead to a 6 percent increase in new TTBs.

Returning to Table 3, we examine the robustness of our results. Column (2) of Table 3 presents our first sensitivity analysis by substituting the change in the domestic unemployment rate at time $t-1$ for domestic real GDP growth as the measure of the health of the domestic economy. The results are broadly consistent with those reported in column (1). The IRR of 1.20 on the change in the domestic unemployment rate indicates that temporary trade barriers increase substantially in the year following an increase in unemployment. Furthermore, as shown in Figure 2, a one standard deviation increase in the change in the domestic unemployment rate leads to a 31 percent increase in the number of products subject to TTBs. Quantitatively, the results using this measure are almost the 
same as that using real GDP growth. While the change in the domestic unemployment rate variable is the preferred measure of the domestic macroeconomic shock in the analysis of high-income economies of Bown and Crowley (2013a), the lack of good unemployment rate data for China and India in particular means that those countries are excluded from any analysis using the unemployment rate; furthermore, it shortens the available time series of data for other countries. For this reason, we generally emphasize the results which use real GDP growth as the measure of the domestic economy.

Columns (3) through (7) demonstrate the robustness of our baseline estimates for 1995-2010 to various other checks. Column (3) replaces the set of bilateral importer-exporter indicators with a set of importer indicators and a separate set of exporter indicators. The IRRs for the variables of interest exhibit little qualitative change from the baseline specification. Nevertheless, this approach also allows us to report the IRR on the indicator that the trading partner is China. The estimated IRR of 9.09 indicates that, controlling for other factors, China's exporters are roughly nine times more likely than the omitted exporting country (defined as the median targeted exporter in the sample) to face import protection through TTBs. ${ }^{18}$

In column (4), we omit bilateral import growth in order to examine the possibility that identifying foreign-induced shocks through inclusion of both foreign real GDP growth and import growth may be collinear. While omission of imports does increase the size of the effect for the estimated IRR on the foreign real GDP growth slightly, the estimated IRRs on the other variables of interest are virtually unchanged.

Column (5) presents an alternative characterization of the dependent variable by narrowing it to consider only the bilateral count of products subject to the antidumping policy alone. Specifically, we redefine the dependent variable to be the bilateral count of products subject to new antidumping investigations that result in imposed import restrictions, thereby leaving out the other TTB policies of safeguards and countervailing duties. As Table 2 indicates, the count of products subject to new antidumping protection in a year is considerably smaller than that of all temporary trade barriers, averaging almost 1 fewer product per year per trading partner. Nevertheless, most of our key results in Table 3 continue to hold even when restricting attention to antidumping in isolation. In particular, the IRRs for the percent change in the bilateral real exchange rate and domestic real GDP growth are

\footnotetext{
${ }^{18}$ In this particular sample, the median targeted exporter was Australia, which cumulatively had 120 distinct HSO6 product-importer combinations hit with new TTBs during this period, compared to 1446 HSO6 productimporter combinations for China's exporters.
} 
statistically different from one, and as Figure 2 indicates, the estimated size of negative real GDP growth shocks is even larger for antidumping alone than all TTBs jointly. One notable difference from the baseline results is that GDP growth in a foreign trading partner has no statistically significant impact on the number of products subject to antidumping. Finally, the general time trend across all of the countries in this sample is that antidumping alone is on average declining over 1995-2010. ${ }^{19}$

Column (6) presents a still different approach to construction of the dependent variable whereby we broaden it (relative to the baseline) to include the count of all products subject to TTB investigations, including those that may not have resulted in the imposition of new import restrictions. The results are qualitatively unchanged according to the estimated IRRs and the magnitudes of the effects illustrated in Figure 2. If anything, TTB investigations alone (relative to imposed barriers of the baseline definition) appear slightly more responsive to domestic real GDP shocks and slightly less responsive to real exchange rate appreciations. Furthermore, the overall time trend of products subject to new investigations during this period is strongly increasing.

Finally, column (7) of Table 3 presents the results from the empirical model of temporary trade barriers for an important subsample of emerging economies G20 members; i.e., Argentina, Brazil, China, India, Indonesia, Mexico, South Africa, and Turkey. ${ }^{20}$ The results for this set of countries are broadly similar to those for the larger sample of emerging economies.

\section{Investigating the Impact of the WTO on New Import Protection}

Thus far our estimates for the emerging economies' use of TTBs have been undertaken on samples of data beginning in 1995. Our argument is that this is the period during which emerging economies faced a relatively common set of rules under the WTO regarding how to implement import protection through TTB policies. In this section we investigate empirically whether this new environment has affected how aggregate-level shocks feed into new import protection by identifying potential changes across time associated with the GATT versus WTO institutional regimes. We are able to do so because

\footnotetext{
${ }^{19}$ Bown (2012a) shows country-by-country evidence for which the overall increase in TTB import coverage over this period is due to inclusion of TTB policies such as safeguards.

${ }^{20}$ Collectively, by 2010 these eight countries accounted for 18 percent of world merchandise imports and 20 percent of world GDP.
} 
a number of emerging economies had already established and were using TTB policies prior to $1995 .^{21}$ Here we exploit that information in order to shed additional light on the impact of the WTO institution by comparing emerging economy use of import protection through TTBs prior to 1995 with their use under the WTO period of 1995-2010.22

Furthermore, in this section we also introduce and examine the implications for the potential role of trade policy substitution taking place within a country over time due to WTO membership. As described in Section 2, when these countries joined the WTO, they committed to binding limits on their more generally applied MFN tariffs. As the share of a country's products that are bound by those limits fluctuates over time - e.g., to the phase-in of scheduled trade liberalization commitments there may be a change within a country regarding its need to access other forms of import protection such as TTBs in response to shocks.

Table 4 presents our results. Column (1) takes our baseline model specification from Table 3, introduces a longer time series of data for TTB-using countries for which policy use prior to 1995 is available, and interacts each of the key determinants with an indicator for whether the year was during the GATT (1989-1994) or WTO (1995-2010) period. For each of the estimated IRRs, the table also reports the test statistic for whether there is a difference between the estimated IRR of the GATT and WTO periods. The evidence indicates a number of important channels through which aggregatelevel fluctuations differentially affect import protection through TTBs under the WTO relative to the GATT period.

The first and direct effect of the change in the institutional environment is captured by the estimated IRR on the dummy variable for the WTO period. Specification (1) reports an IRR of 1.84 that is statistically different from 1 indicating that, controlling for a number of other factors, on average these countries use more TTBs under the WTO relative to the GATT.

For real exchange rates, the estimated IRRs are significantly greater than 1 for the WTO period, indicating that appreciations are associated with subsequent increases in import protection.

\footnotetext{
${ }^{21}$ Table 1 documents the first year for which the sample begins for each policy-imposing economy, based on its initial use of TTBs during our sample period.

22 To be precise, our analysis does compare the period of WTO membership against the "pre-membership" period - and not the GATT period - for one of the countries in our sample. I.e., for China we consider differential impacts of its years as a WTO member (2002-2010) with its years of TTB use prior to joining the WTO (1997-2001). For all other countries in the sample we compare 1995-2010 with the pre-1995 period since all other countries in the sample joined the WTO in 1995.
} 
However, this is also a statistically significant change relative to the impact of real exchange rate movements on TTB import protection during the GATT period. Over 1989-1994, real exchange rate depreciations (IRR of 0.99) were associated with new import protection. While the IRR for the 19891994 period is imprecisely estimated, it is statistically different from the estimated IRR of 1.01 for the 1995-2010 period.

The second important result of specification (1) is that over the period 1995-2010, there is a strong counter-cyclical relationship between lagged domestic real GDP growth and new import protection. This is also distinct from the role this variable took on prior to the WTO; the estimated IRR for the 1989-1994 period is 1.05. While the estimated IRR on real GDP growth for the 1989-1994 period is also imprecisely estimated, it is also statistically different from the estimated IRR of the 1995-2010 period.

One way to interpret these two pieces of evidence is that the inception of the WTO in 1995 has coincided with a change in behavior as emerging economies began to respond to macroeconomic shocks by using new TTB import protection in the same way that high-income economies had been doing since at least the 1980s. ${ }^{23}$ The evidence suggests a significant change for these emerging economies relative to the pre-WTO period of 1989-1994, during which factors other than aggregatelevel shocks apparently led to new import protection under TTB policies.

The results of the next two variables from column (1) are mixed. First, the estimated IRRs on lagged trading partner real GDP growth are statistically less than one in both periods. However, the estimated IRRs are statistically different from one another, and interestingly, the IRR from the GATT period is even further away from one than the IRR from the WTO period. This result suggests that import protection for these countries has become less responsive to negative foreign real GDP shocks after 1995. Some of this is explained by the relatively short sample of the pre-WTO period which happens to coincides with foreign recessions (or low growth periods) for significant trading partners (exporters), such as the United States and European Union. ${ }^{24}$ This is also partly explained by the composition of targeted trading partners in the post-1995 period shifting so dramatically toward

\footnotetext{
${ }^{23}$ See Bown and Crowley (2013a) as well as Knetter and Prusa (2003).

${ }^{24}$ This also technically holds for China for its "pre-WTO" use of TTBs which began in 1997 and yet its particular WTO membership period did not begin until the end of 2001 when its accession was implemented. During its particular pre-WTO period, its use of TTBs targeted important exporters like South Korea and Japan during the Asian financial crisis, as well as Russia during its crisis in 1999.
} 
China, a trading partner with extremely strong (and relatively non-volatile) real GDP growth during this period. ${ }^{25}$ Second, while the estimated IRRs on bilateral import growth switch from being less than one (GATT period) to greater than one (WTO period), neither IRR is estimated as different from one and the test indicates that the estimates are not statistically different from one another. Thus there is only weak evidence that import protection through TTBs has become more sensitive to bilateral import growth surges under the WTO relative to the GATT.

Column (2) of Table 4 presents our paper's preferred specification whereby we modify the baseline model to include the new variable introduced in Section 2, defined as the lagged change in the share of HSO6 products under WTO discipline - i.e., the share of products that are constrained by WTO maximum tariff limits because the applied tariff on a product is equal to its legal binding rate. ${ }^{26}$ Again, we expect the IRR on this variable to be greater than 1, so that over time as more applied MFN tariffs become legally immovable in an upward direction, more of a country's aggregate demand for new import protection pushes toward TTBs in response to economic shocks. The estimated IRR is 1.04 and it is statistically significant. Furthermore, the rest of the estimated IRRs for the variables of interest in the estimation in column (2) are qualitatively unchanged.

With these estimates in mind, next consider Figure 3 which presents additional information on the economic magnitudes of the effects. Results corresponding to the GATT era are represented by a solid grey bar (specification 2 in Table 4) and a horizontally striped bar (specification 4 in Table 4). The corresponding results for the WTO era are represented by a black bar (specification 2 of Table 4) and a vertically striped bar (specification 4 in Table 4). The first striking differences are seen in the impact of real currency appreciations. During the GATT period before 1995, a one standard deviation appreciation led to 12-33 percent fewer TTBs in the following year. This is a dramatic difference in comparison to the WTO period. Under the WTO, a one standard deviation appreciation of the bilateral real exchange rate led to a 23-31 percent increase in the number of TTBs imposed.

The next group of bars in Figure 3 indicates that, prior to the WTO, weak real GDP growth or increases in the unemployment rate led to small declines in TTBs the following year. In sharp contrast,

\footnotetext{
${ }^{25}$ For the countries in the sample, almost 25 percent of all HSO6 import products impacted by TTBs during this period targeted exports from China, during a period in which its mean annual real GDP growth rate was 10.09 percent with a standard deviation of 1.90 .

${ }^{26}$ This variable is interacted with a binary indicator for the WTO period, under the assumption that this channel was not relevant during the GATT period when most emerging economies had not made significant legal binding commitments on their applied MFN tariffs.
} 
a one standard deviation decline in real GDP growth (increase in the change in the domestic unemployment rate) under the WTO has been associated with a 25 percent ( 37 percent) increase in TTBs in the subsequent year.

The third group of bars more precisely quantifies the results on trading partner growth. In particular, weak trading partner growth is quantitatively much less important under the WTO period.

Finally, the last group of bars shows how commitments over MFN applied tariffs - or reductions in available policy space - help push countries toward utilizing TTB policies. As the share of products with binding tariff commitments increases by one standard deviation, the number of TTBs increases by 24 percent and 48 percent in specifications (2) and (4), respectively. While these results do indicate that countries are stepping away from the liberal trade regime and their promises to lower and bind their applied tariffs, it also represents a commitment to abide by the WTO's rules and use the WTO's sanctioned policy tools of TTBs in response to economic shocks.

The rest of Table 4 presents a set of robustness checks and sensitivity analysis. First, in column (3) we modify the definition for the WTO tariff binding variable. Here we redefine the share of products under WTO discipline so that any HS-06 product with an applied import tariff within 10 percentage points of its tariff binding is "under WTO discipline," a less restrictive condition than considering only products with applied tariffs equal to the binding. Use of this alternative measure has only a small impact on the size of the estimated IRRs.

In column (4), we employ our alternative measure for the health of the domestic economy, substituting the lagged change in the domestic unemployment rate for domestic real GDP growth. The results are consistent with those obtained earlier - i.e., in the GATT period, the estimated IRR is less than one (though not significant) indicating that periods of lower unemployment were associated with heightened import protection through TTBs. While the differential between these two estimated IRRs is not statistically significant in this sample of data, part of this is likely explained by the poorer quality of unemployment data during the early period, in terms of how accurately such measures captured the health of the domestic economy, given the role of the informal sector. ${ }^{27}$ Furthermore, because the sample of countries for which the unemployment data is available at all is significantly

\footnotetext{
${ }^{27}$ Even for emerging economies with available unemployment rate data included in the sample, the argument is that unemployment rate itself may be becoming a more accurate and representative indicator for the overall health of the domestic economy over time due to the role that the informal sector plays in many countries. I.e., unemployment rate data for these countries may be noisier earlier in the sample if there is a general upward trend in formality within a country over time.
} 
reduced, in column (5) we rerun our preferred model specification (of column 2) but with the same restricted subsample of data underlying the results in column (4). The basic results hold, indicating that the estimates are not sensitive to dropping major policy-imposing countries such as India and China from the sample due to the lack of unemployment data for this period.

Finally, in specification (6) we again estimate our preferred specification of the model, but in this case we only include the subsample of major G20 emerging economies. In each instance, the qualitative pattern of the results holds.

\section{Conclusion}

Many emerging economies now exceed high income economies in the frequency and intensity of their application of the import-restricting antidumping, safeguards, and countervailing duty policies collectively referred to as temporary trade barriers (TTBs). This paper investigates the impact of macroeconomic shocks on these trade policies for thirteen emerging economies between 1989 and 2010. We provide evidence of a general counter-cyclical relationship for the period 1995-2010 under the WTO. We also provide evidence on changes to these empirical relationships relative to the preWTO period; i.e., emerging economy import protection through TTBs became more counter-cyclical and sensitive to real exchange rate shocks over time.

Our approach allows us to examine not only the impact of the WTO institution on aggregatelevel channels for new import protection, but we also explicitly address the separate role played by WTO disciplines on a country's access to other trade policies such as applied MFN import tariffs. For these emerging economies, we find that an increase in the share of a country's imported products that become subject to WTO disciplines results in significantly more products facing import protection through TTBs. Nevertheless, our aggregate-level evidence on trade policy substitutability between applied import tariffs and application of TTBs does not fully resolve the question of why many emerging economies use TTBs to respond to economic shocks despite the significant "water" that remains in their tariff bindings. Some of these countries retain considerable freedom under the WTO to raise applied MFN tariffs, and yet they frequently respond to aggregate-level shocks with more discriminatory, trading partner-specific TTBs such as antidumping. These puzzles merit further microoriented theoretical and empirical research. 


\section{References}

Bagwell, Kyle and Robert W. Staiger (1990) "A Theory of Managed Trade," American Economic Review 80(4): 779-795.

Bagwell, Kyle and Robert W. Staiger (1999) "An Economic Theory of GATT," American Economic Review 89(1): 215-248.

Bagwell, Kyle and Robert W. Staiger (2003) "Protection and the Business Cycle," Advances in Economic Analysis \& Policy 3(1): 1-43.

Bagwell, Kyle and Robert W. Staiger (2011) "What Do Trade Negotiators Negotiate About? Empirical Evidence from the World Trade Organization," American Economic Review 101(4): 1238-73.

Blonigen, Bruce A. and Thomas J. Prusa (2003) "Antidumping," in James Harrigan and E. Kwan Choi (Eds.) Handbook of International Trade. Cambridge, MA: Blackwell Publishers.

Bown, Chad P. (2008) "The WTO and Antidumping in Developing Countries," Economics and Politics 20(2): 255-288.

Bown, Chad P. (2011) "Taking Stock of Antidumping, Safeguards and Countervailing Duties, 19902009," The World Economy 34(12): 1955-1998.

Bown, Chad P. (2012a) "Emerging Economies and the Emergence of South-South Protectionism," World Bank Policy Research Working Paper No. 6162, August.

Bown, Chad P. (2012b) Temporary Trade Barriers Database, The World Bank. Available on line at http://econ.worldbank.org/ttbd/, May.

Bown, Chad P. and Meredith A. Crowley (2013a) "Import Protection, Business Cycles, and Exchange Rates: Evidence from the Great Recession," Journal of International Economics 90(1): 50-64.

Bown, Chad P. and Meredith A. Crowley (2013b) "Self-Enforcing Trade Agreements: Evidence from Time-Varying Trade Policy," American Economic Review 103(2): 1071-1090.

Bown, Chad P. and Patricia Tovar (2011) "Trade Liberalization, Antidumping, and Safeguards: Evidence from India's Tariff Reform," Journal of Development Economics 96(1): 115-125.

Broda, Christian, Nuno Limão, and David E. Weinstein. (2008) "Optimal Tariffs and Market Power: The Evidence," American Economic Review 98(5): 2032-65.

Bussiere, Matthieu, Emilia Perez-Barreiro, Roland Straub, and Daria Taglioni (2010) “Protectionist Responses to the Crisis: Global Trends and Implications," ECB Occasional Paper Series No. 110.

Crowley, Meredith A. (2010) "Split Decisions in Antidumping Cases," B.E. Journal of Economic Analysis and Policy 10(1), Article 68.

Crowley, Meredith A. (2011) "Cyclical Dumping and US Antidumping Protection: 1980-2001," Federal Reserve Bank of Chicago Working Paper No. 2007-21.

Davis, Christina and Krzysztof J. Pelc (2012) "Cooperation in Hard Times: Self-Restraint of Trade Protection," Princeton University manuscript, June. 
Feinberg, Robert M. (1989) "Exchange Rates and Unfair Trade," The Review of Economics and Statistics 71 (4): 704-707.

Gawande, Kishore, Bernard Hoekman, and Yue Cui (2014) "Global Supply Chains and Trade Policy Responses to the 2008 Crisis," World Bank Economic Review , forthcoming.

Grossman, Gene M., and Elhanan Helpman (1994) "Protection for Sale," American Economic Review 84(4): 833-850.

Hausman, Jerry, Bronwyn H Hall, and Zvi Griliches (1984) "Econometric Models for Count Data with an Application to the Patents-R\&D Relationship," Econometrica 52(4): 909-938.

Irwin, Douglas A. (2011) Peddling Protectionism: Smoot-Hawley and the Great Depression. Princeton, NJ: Princeton University Press

Irwin, Douglas A. (2012) Trade Policy Disaster: Lessons from the 1930s. Cambridge, MA: The MIT Press. Kee, Hiau Looi, Cristina Neagu, and Alessandro Nicita (2013) "Is Protectionism on the Rise? Assessing National Trade Policies During the Crisis of 2008," The Review of Economics and Statistics 95(1): 342-346.

Knetter, Michael M. and Thomas J. Prusa (2003) "Macroeconomic Factors and Antidumping Filings: Evidence from Four Countries," Journal of International Economics 61(1): 1-17.

Maggi, Giovanni and Andres Rodriguez-Clare (1998) "The Value of Trade Agreements in the Presence of Political Pressures," Journal of Political Economy 106(3): 574-601.

Maggi, Giovanni and Andres Rodriguez-Clare (2007) "A Political-Economy Theory of Trade Agreements," American Economic Review 97(4): 1374-1406.

Rose, Andrew K. (2004) "Do We Really Know That the WTO Increases Trade?," American Economic Review 94(1): 98-114.

Rose, Andrew K. (2013) "The March of an Economic Idea? Protectionism isn't Counter-cyclic (Anymore)," Economic Policy 28(76): 569-612.

Staiger, Robert W. and Guido Tabellini (1987) "Discretionary Trade Policy and Excessive Protection," American Economic Review 77(5): 823-37.

Staiger, Robert W. and Frank A. Wolak (1994) "Measuring Industry-Specific Protection: Antidumping in the United States," Brookings Papers on Economic Activity: Microeconomics 51-118.

Subramanian, Arvind and Shang-Jin Wei (2007) "The WTO Promotes Trade: Strongly But Unevenly," Journal of International Economics 72(1): 151-175.

Tang, Man-Keung and Shang-Jin Wei (2009) "The Value of Making Commitments Externally: Evidence from WTO Accessions," Journal of International Economics 78(2): 216-22.

WTO (2011) World Tariff Profiles 2011. Geneva: WTO, UNCTAD and International Trade Centre. 


\section{Appendix: Data Description}

Antidumping, safeguards, and countervailing duty policy data at the Harmonized System 6-digit level by trading partner for $1995-2010$ is compiled by the authors from the World Bank's Temporary Trade Barriers Database (Bown, 2012b) which is publicly available at http://econ.worldbank.org/ttbd/ .

Bilateral real exchange rate series come from the USDA's Agricultural Exchange Rate Dataset. For each observation we use the value as of the last month of the year.

Real GDP growth series comes from IMF's IFS series with the exception of the European Union. For the European Union, we use the OECD's real GDP series for the EU-15.

Domestic unemployment rate change is constructed with data from the International Labor Organization.

WTO disciplines over tariff come from 6-digit Harmonized System tariff data (simple averages) by country from TRAINS and WTO.

Trading Partners: For each of the thirteen policy-imposing economies, we start with the 20 trading partners that are the most frequent targets against which each economy used TTBs over the sample period. From there, we include all of the top 20 trading partners for which we have quality macroeconomic data. This reduces the number of included partners to between 10 and 14 . The reported information on percent of imports is based on non-oil imports during the 1995-2010 period. The trading partners for each policy-imposing economy used in the sample are:

- Argentina (14): Australia, Brazil, China, European Union, India, Indonesia, Malaysia, Paraguay, Russia, South Africa, South Korea, Switzerland, Thailand, United States. These economies were the source of 85 percent of imports.

- Brazil (13): Argentina, Chile, China, European Union, India, Japan, Mexico, Pakistan, Russia, South Africa, South Korea, Thailand, United States. These economies were the source of 84 percent of imports.

- China (10): European Union, India, Indonesia, Japan, Malaysia, Russia, Singapore, South Korea, Thailand, United States. These economies were the source of 67 percent of imports. 
- Colombia (12): Brazil, China, European Union, Indonesia, Malaysia, Mexico, Russia, Thailand, South Korea, Trinidad and Tobago, United States, Venezuela. These economies were the source of 75 percent of imports.

- India (13): Canada, China, European Union, Indonesia, Japan, Malaysia, Russia, Saudi Arabia, Singapore, South Africa, South Korea, Thailand, United States. These economies were the source of 69 percent of imports.

- Indonesia (11): Australia, China, European Union, India, Japan, Malaysia, Russia, Singapore, South Korea, Thailand, Turkey. These economies were the source of 74 percent of imports.

- Malaysia (12): Australia, Canada, China, European Union, Hong Kong, China; India, Indonesia, Japan, Philippines, South Korea, Thailand, United States. These economies were the source of 77 percent of imports.

- Mexico (12): Argentina, Brazil, Canada, China, Colombia, European Union, Hong Kong, China; Japan, Pakistan, Russia, South Korea, United States. These economies were the source of 91 percent of imports.

- Peru (12): Argentina, Brazil, Chile, China, Colombia, European Union, India, Indonesia, Mexico, Pakistan, Russia, United States. These economies were the source of 77 percent of imports.

- Philippines (8): China, European Union, Hong Kong, China; Indonesia, Malaysia, Russia, South Korea, Thailand. These economies were the source of 38 percent of imports.

- South Africa (13): Australia, Brazil, China, European Union, Hong Kong, China; India, Indonesia, Pakistan, Russia, South Korea, Thailand, Turkey, United States. These economies were the source of 78 percent of imports.

- Thailand (11): Argentina, China, European Union, India, Indonesia, Japan, Malaysia, Russia, South Africa, South Korea, Venezuela. These economies were the source of 65 percent of imports.

- Turkey (13): China, Egypt, European Union, Hong Kong, China; India, Indonesia, Israel, Malaysia, Pakistan, Russia, Saudi Arabia, South Korea, Thailand. These economies were the source of 73 percent of imports. 
Table 1: Temporary Trade Barriers and WTO Disciplines over MFN Tariffs

\begin{tabular}{|c|c|c|c|c|c|c|c|c|c|c|}
\hline Economy & $\begin{array}{l}\text { MFN tariff } \\
\text { binding } \\
\text { coverage } \\
\text { under WTO } \\
\text { (1) }\end{array}$ & $\begin{array}{c}\text { Average } \\
\text { bound MFN } \\
\text { tariff rate } \\
\text { under WTO } \\
\text { (2) }\end{array}$ & $\begin{array}{l}\text { Average } \\
\text { applied } \\
\text { MFN tariff } \\
\text { rate in } \\
1995^{*} \\
(3)\end{array}$ & $\begin{array}{l}\text { Average } \\
\text { applied MFN } \\
\text { tariff rate in } \\
2010 \\
\text { (4) }\end{array}$ & $\begin{array}{l}\text { TTB import } \\
\text { product } \\
\text { coverage } \\
\text { in } 1995 \\
\text { (5) }\end{array}$ & $\begin{array}{l}\text { TTB import } \\
\text { product } \\
\text { coverage } \\
\text { in } 2010 \\
(6)\end{array}$ & $\begin{array}{c}\text { Year of } \\
\text { first TTB in } \\
\text { our } \\
\text { estimation } \\
\text { (7) }\end{array}$ & $\begin{array}{c}\text { Share of } \\
\text { products with } \\
\text { imposed TTBs } \\
\text { under WTO } \\
\text { discipline, } \\
\text { 1995-2010 } \\
\text { (8) }\end{array}$ & $\begin{array}{l}\text { Share of } \\
\text { products with } \\
\text { new TTB } \\
\text { imposed } \\
\text { under WTO } \\
\text { discipline, } \\
\text { 1995-2010 } \\
\text { (9) }\end{array}$ & $\begin{array}{c}\text { Share of } \\
\text { products with } \\
\text { no new TTB } \\
\text { imposed } \\
\text { under WTO } \\
\text { discipline, } \\
\text { 1995-2010 } \\
(10)\end{array}$ \\
\hline \multicolumn{11}{|c|}{ Emerging economy G20 members in sample } \\
\hline Argentina & 100.0 & 31.9 & 12.1 & 12.5 & 1.3 & 3.3 & 1989 & 18.3 & 20.2 & 15.3 \\
\hline Brazil & 100.0 & 31.4 & 13.0 & 13.7 & 0.4 & 1.6 & 1989 & 39.4 & 27.3 & 17.6 \\
\hline China & 100.0 & 10.0 & 15.9 & 9.6 & 0.0 & 1.4 & 1997 & 76.8 & 67.9 & 67.3 \\
\hline India & 73.8 & 49.4 & 14.5 & 12.4 & 0.2 & 6.6 & 1992 & 55.4 & 49.4 & 30.1 \\
\hline Indonesia & 95.8 & 37.2 & 15.3 & 6.7 & 0.0 & 0.6 & 1996 & 12.0 & 12.7 & 8.4 \\
\hline Mexico & 100.0 & 35.0 & 13.1 & 8.9 & 24.1 & 1.2 & 1989 & 3.8 & 9.0 & 8.1 \\
\hline South Africa & 96.6 & 19.2 & 14.2 & 7.6 & 0.4 & 0.6 & 1992 & 77.4 & 78.1 & 63.0 \\
\hline Turkey & 50.4 & 28.5 & 9.4 & 9.9 & 0.7 & 6.9 & 1989 & 3.7 & 4.4 & 25.6 \\
\hline \multicolumn{11}{|c|}{ Emerging economy non-G20 members in sample } \\
\hline Colombia & 100.0 & 42.9 & 13.7 & 12.5 & 0.1 & 0.8 & 1991 & 0.0 & 0.0 & 0.3 \\
\hline Malaysia & 84.3 & 14.6 & 8.1 & 7.0 & 0.0 & 0.1 & 1996 & 24.9 & 32.7 & 69.1 \\
\hline Peru & 100.0 & 30.1 & 16.5 & 5.4 & 0.2 & 2.5 & 1992 & 27.0 & 37.1 & 12.9 \\
\hline Philippines & 67.0 & 25.7 & 20.3 & 6.3 & 0.0 & 0.2 & 1994 & 11.1 & 10.0 & 19.1 \\
\hline Thailand & 75.0 & 25.7 & 23.1 & 9.7 & 0.0 & 0.5 & 1996 & 0.0 & 32.6 & 27.9 \\
\hline
\end{tabular}

Source: All data computed from the HS-06 level. Column (1) is from WTO (2011), columns (2), (3), and (4) are calculated by the authors from WITS, columns (5) and

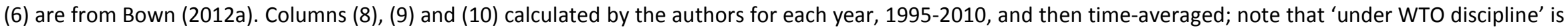

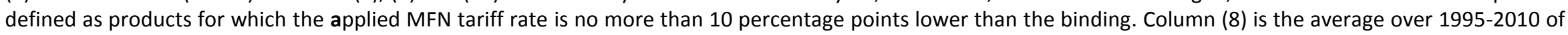

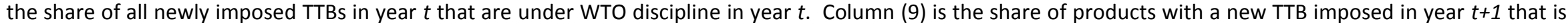

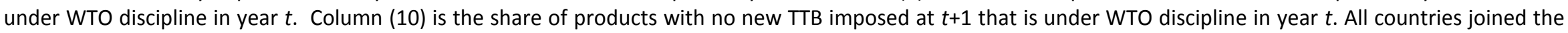

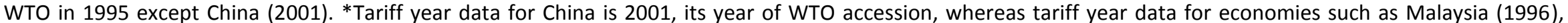
South Africa (1996), and India (1997) is the first year available after 1995. 
Table 2: Summary Statistics

\begin{tabular}{|c|c|c|c|c|}
\hline \multirow[b]{2}{*}{ Variables } & \multicolumn{2}{|c|}{$\begin{array}{c}\text { Full sample of } \\
13 \text { emerging economies }\end{array}$} & \multicolumn{2}{|c|}{$\begin{array}{l}\text { G20 emerging } \\
\text { economies only }\end{array}$} \\
\hline & $1995-2010$ & 1989-1994 & $1995-2010$ & 1989-1994 \\
\hline \multicolumn{5}{|l|}{ Dependent Variables } \\
\hline $\begin{array}{l}\text { Bilateral }(i j) \text { count of products initiated } \\
\text { under all temporary trade barrier (TTB) } \\
\text { policies in year } t \text { that result in import } \\
\text { protection (products per year per trading } \\
\text { partner }\end{array}$ & $\begin{array}{c}2.52 \\
(8.69)\end{array}$ & $\begin{array}{c}0.88 \\
(3.26)\end{array}$ & $\begin{array}{l}3.39 \\
(9.86)\end{array}$ & $\begin{array}{c}1.01 \\
(3.57)\end{array}$ \\
\hline $\begin{array}{l}\text { Bilateral ( } i j) \text { count of products initiated } \\
\text { under all temporary trade barrier (TTB) } \\
\text { policies in year } t \text { (products per year per } \\
\text { trading partner) }\end{array}$ & $\begin{array}{c}5.26 \\
(23.39)\end{array}$ & $\begin{array}{c}3.14 \\
(12.70)\end{array}$ & $\begin{array}{c}4.88 \\
(11.68)\end{array}$ & $\begin{array}{c}3.74 \\
(13.95)\end{array}$ \\
\hline $\begin{array}{l}\text { Bilateral (ij) count of products initiated } \\
\text { under antidumping (AD) policies in year } t \\
\text { that result in import protection (products } \\
\text { per year per trading partner) }\end{array}$ & $\begin{array}{c}1.66 \\
(5.70)\end{array}$ & $\begin{array}{c}0.91 \\
(3.35)\end{array}$ & $\begin{array}{c}1.69 \\
(5.87)\end{array}$ & $\begin{array}{c}1.05 \\
(3.68)\end{array}$ \\
\hline \multicolumn{5}{|l|}{ Explanatory Variables } \\
\hline $\begin{array}{l}\text { Percent change in bilateral real exchange } \\
\text { rate ijt-1 }\end{array}$ & $\begin{array}{c}1.39 \\
(18.35)\end{array}$ & $\begin{array}{c}13.71 \\
(65.84)\end{array}$ & $\begin{array}{c}1.62 \\
(19.66)\end{array}$ & $\begin{array}{c}15.78 \\
(71.79)\end{array}$ \\
\hline Domestic real GDP growth $j t-1$ & $\begin{array}{c}4.50 \\
(4.28)\end{array}$ & $\begin{array}{c}3.66 \\
(3.86)\end{array}$ & $\begin{array}{c}4.42 \\
(4.39)\end{array}$ & $\begin{array}{c}3.76 \\
(4.16)\end{array}$ \\
\hline $\begin{array}{l}\text { Change in domestic unemployment rate } j t \text { - } \\
1^{*}\end{array}$ & $\begin{array}{c}0.07 \\
(1.46)\end{array}$ & $\begin{array}{c}0.23 \\
(1.12)\end{array}$ & $\begin{array}{c}0.04 \\
(1.68)\end{array}$ & $\begin{array}{c}0.37 \\
(1.06)\end{array}$ \\
\hline Real GDP growth of trading partner it-1 & $\begin{array}{l}4.17 \\
(4.17)\end{array}$ & $\begin{array}{c}4.98 \\
(4.09)\end{array}$ & $\begin{array}{c}4.09 \\
(4.03)\end{array}$ & $\begin{array}{c}4.87 \\
(4.09)\end{array}$ \\
\hline $\begin{array}{l}\text { Bilateral import growth from trading } \\
\text { partner ijt-1 }\end{array}$ & $\begin{array}{c}6.74 \\
(91.87)\end{array}$ & $\begin{array}{c}0.95 \\
(5.69)\end{array}$ & $\begin{array}{c}10.25 \\
(113.86)\end{array}$ & $\begin{array}{c}0.92 \\
(6.15)\end{array}$ \\
\hline $\begin{array}{l}\text { Change in the share of imported products } \\
\text { under WTO discipline } j t-1^{*}\end{array}$ & $\begin{array}{l}-1.05 \\
(6.08)\end{array}$ & -- & $\begin{array}{l}-0.80 \\
(4.45)\end{array}$ & -- \\
\hline Observations & 2373 & 459 & 1541 & 377 \\
\hline
\end{tabular}


Table 3: Negative Binomial Model Estimates of Determinants of Import Protection, 1995-2010

Dependent variable: Bilateral $(i j)$ count of products initiated under all temporary trade barrier (TTB) policies in year $t$ that result in import protection

\begin{tabular}{|c|c|c|c|c|c|c|c|}
\hline Explanatory Variables & $\begin{array}{c}\text { Baseline } \\
\text { specification } \\
\text { (1) }\end{array}$ & $\begin{array}{c}\text { Substitute } \\
\text { domestic un- } \\
\text { employment } \\
\text { (2) }\end{array}$ & $\begin{array}{c}\text { Modify } \\
\text { country } \\
\text { indicators } \\
\text { (3) }\end{array}$ & $\begin{array}{c}\text { Drop } \\
\text { import } \\
\text { growth } \\
\text { (4) }\end{array}$ & $\begin{array}{c}\text { Redefine } \\
\text { dependent } \\
\text { variable to } \\
\text { AD only } \\
\text { (5) }\end{array}$ & $\begin{array}{c}\text { Redefine } \\
\text { dependent } \\
\text { variable to all } \\
\text { TTB } \\
\text { investigations } \\
\text { (6) }\end{array}$ & $\begin{array}{c}\text { G20 } \\
\text { emerging } \\
\text { economies } \\
\text { only } \\
\text { (7) }\end{array}$ \\
\hline Percent change in bilateral real exchange rate ijt-1 & $\begin{array}{l}1.01^{b} \\
(2.30)\end{array}$ & $\begin{array}{l}1.01^{\mathrm{b}} \\
(2.10)\end{array}$ & $\begin{array}{l}1.01^{b} \\
(2.04)\end{array}$ & $\begin{array}{l}1.01^{\mathrm{b}} \\
(2.25)\end{array}$ & $\begin{array}{l}1.01^{b} \\
(2.30)\end{array}$ & $\begin{array}{c}1.01^{\mathrm{C}} \\
(1.69)\end{array}$ & $\begin{array}{l}1.01^{b} \\
(2.00)\end{array}$ \\
\hline Domestic real GDP growth $j t-1$ & $\begin{array}{c}0.94^{\mathrm{a}} \\
(3.56)\end{array}$ & -- & $\begin{array}{l}0.96^{b} \\
(2.35)\end{array}$ & $\begin{array}{c}0.94^{\mathrm{a}} \\
(3.60)\end{array}$ & $\begin{array}{c}0.92^{\mathrm{a}} \\
(4.26)\end{array}$ & $\begin{array}{l}0.93^{\mathrm{a}} \\
(4.37)\end{array}$ & $\begin{array}{c}0.93^{\mathrm{a}} \\
(3.56)\end{array}$ \\
\hline Domestic unemployment rate change $j t-1$ & -- & $\begin{array}{l}1.20^{\mathrm{a}} \\
(2.85)\end{array}$ & -- & -- & -- & -- & -- \\
\hline Real GDP growth of trading partner it-1 & $\begin{array}{c}0.97^{\mathrm{c}} \\
(1.86)\end{array}$ & $\begin{array}{c}0.98 \\
(0.65)\end{array}$ & $\begin{array}{c}0.97^{c} \\
(1.79)\end{array}$ & $\begin{array}{c}0.96^{\mathrm{C}} \\
(1.94)\end{array}$ & $\begin{array}{c}1.01 \\
(0.54)\end{array}$ & $\begin{array}{c}0.97^{c} \\
(1.86)\end{array}$ & $\begin{array}{c}0.98 \\
(1.19)\end{array}$ \\
\hline Bilateral import growth from trading partner ijt-1 & $\begin{array}{c}1.00 \\
(0.95)\end{array}$ & $\begin{array}{c}1.15 \\
(0.57)\end{array}$ & $\begin{array}{c}1.00 \\
(0.22)\end{array}$ & -- & $\begin{array}{c}1.00 \\
(1.21)\end{array}$ & $\begin{array}{c}1.00 \\
(0.72)\end{array}$ & $\begin{array}{c}1.00 \\
(0.99)\end{array}$ \\
\hline Time trend & $\begin{array}{c}1.02 \\
(1.62)\end{array}$ & $\begin{array}{c}0.97 \\
(1.04)\end{array}$ & $\begin{array}{c}1.01 \\
(0.41)\end{array}$ & $\begin{array}{c}1.02 \\
(1.57)\end{array}$ & $\begin{array}{l}0.97^{\mathrm{b}} \\
(2.09)\end{array}$ & $\begin{array}{l}1.06^{\mathrm{a}} \\
(3.95)\end{array}$ & $\begin{array}{l}1.03^{\mathrm{c}} \\
(1.83)\end{array}$ \\
\hline Indicator that exporter is China* & -- & -- & $\begin{array}{c}9.09^{\mathrm{a}} \\
(5.26)\end{array}$ & -- & -- & -- & -- \\
\hline Importer-exporter combined fixed effects & yes & yes & no & yes & yes & yes & yes \\
\hline Separate importer and exporter fixed effects & no & no & yes & no & no & no & no \\
\hline Observations & 2,373 & 1,393 & 2,373 & 2,373 & 2,373 & 2,373 & 1,541 \\
\hline
\end{tabular}

Notes: Policy-imposing countries $j$ vis-à-vis one of the trading partners $i$ (listed in the Appendix) over 1995-2010. Explanatory variables are each lagged one year (at $t$-1). Incidence Rate Ratios (IRRs) are reported in lieu of coefficient estimates, with $t$-statistics in parentheses. Model includes a constant term whose estimate is suppressed. Superscripts a, b, and c indicate statistical significance at the 1 percent, 5 percent, and 10 percent levels, respectively. $A D=$ antidumping. *xcluded exporter fixed effect is for the median country by total products targeted by all policy-imposing countries in the sample during 1995-2010, which was Australia. 
Table 4: The Impact of the WTO Agreement on Time-Varying Import Protection

\begin{tabular}{|c|c|c|c|c|c|c|}
\hline \multirow[b]{2}{*}{ Explanatory variables } & \multirow[b]{2}{*}{$\begin{array}{l}\text { Baseline } \\
\text { (1) }\end{array}$} & \multirow[b]{2}{*}{$\begin{array}{l}\text { Add tariff } \\
\text { variable } \\
\text { (2) }\end{array}$} & \multirow[b]{2}{*}{$\begin{array}{c}\text { Change } \\
\text { definition } \\
\text { of tariff } \\
\text { variable } \\
\text { (3) }\end{array}$} & \multirow[b]{2}{*}{$\begin{array}{c}\text { Substitute } \\
\text { unemploy- } \\
\text { ment rate } \\
\text { change } \\
\text { (4) }\end{array}$} & \multirow[b]{2}{*}{$\begin{array}{l}\text { Real GDP } \\
\text { on same } \\
\text { subsample } \\
\text { as (4) } \\
\text { (5) }\end{array}$} & \multirow[b]{2}{*}{$\begin{array}{c}\text { G20 } \\
\text { only } \\
(6)\end{array}$} \\
\hline & & & & & & \\
\hline $\begin{array}{l}\text { Percent change in bilateral real } \\
\text { exchange rate ijt-1 x GATT }\end{array}$ & $\begin{array}{c}0.99 \\
(0.86)\end{array}$ & $\begin{array}{c}0.99 \\
(0.83)\end{array}$ & $\begin{array}{c}0.99 \\
(0.84)\end{array}$ & $\begin{array}{c}0.99^{c} \\
(1.91)\end{array}$ & $\begin{array}{c}0.99 \\
(1.09)\end{array}$ & $\begin{array}{c}0.99 \\
(0.45)\end{array}$ \\
\hline $\begin{array}{l}\text { Percent change in bilateral real } \\
\text { exchange rate ijt-1 } \times \text { WTO }\end{array}$ & $\begin{array}{l}1.01^{\mathrm{a}} \\
(2.75)\end{array}$ & $\begin{array}{l}1.01^{\mathrm{a}} \\
(2.77)\end{array}$ & $\begin{array}{l}1.01^{\mathrm{a}} \\
(2.65)\end{array}$ & $\begin{array}{l}1.01^{\mathrm{b}} \\
(2.06)\end{array}$ & $\begin{array}{l}1.01^{\mathrm{c}} \\
(1.80)\end{array}$ & $\begin{array}{l}1.01^{\mathrm{b}} \\
(2.41)\end{array}$ \\
\hline [Test statistic] & {$[7.99]^{\mathrm{a}}$} & {$[8.01]^{\mathrm{a}}$} & {$[7.44]^{\mathrm{b}}$} & {$[6.57]^{\mathrm{a}}$} & {$[4.21]^{\mathrm{b}}$} & {$[5.54]^{\mathrm{b}}$} \\
\hline Domestic economy jt-1 x GATT & $\begin{array}{l}1.05 \\
(1.11)\end{array}$ & $\begin{array}{l}1.05 \\
(1.15)\end{array}$ & $\begin{array}{l}1.05 \\
(1.14)\end{array}$ & $\begin{array}{c}0.94 \\
(0.29)\end{array}$ & $\begin{array}{l}1.15^{\mathrm{a}} \\
(2.30)\end{array}$ & $\begin{array}{l}1.06 \\
(1.47)\end{array}$ \\
\hline Domestic economy jt-1 x WTO & $\begin{array}{l}0.95^{\mathrm{a}} \\
(2.96)\end{array}$ & $\begin{array}{l}0.95^{\mathrm{a}} \\
(2.97)\end{array}$ & $\begin{array}{l}0.95^{\mathrm{a}} \\
(2.83)\end{array}$ & $\begin{array}{l}1.24^{\mathrm{a}} \\
(3.44)\end{array}$ & $\begin{array}{l}0.94^{\mathrm{b}} \\
(2.03)\end{array}$ & $\begin{array}{l}0.95^{\mathrm{a}} \\
(2.59)\end{array}$ \\
\hline [Test statistic] & {$[4.72]^{\mathrm{b}}$} & {$[4.88]^{\mathrm{b}}$} & {$[4.62]^{\mathrm{b}}$} & [1.57] & {$[8.62]^{\mathrm{a}}$} & {$[6.17]^{\mathrm{b}}$} \\
\hline $\begin{array}{l}\text { Real GDP growth of trading partner } \\
\text { it-1 x GATT }\end{array}$ & $\begin{array}{l}0.85^{\mathrm{a}} \\
(4.12)\end{array}$ & $\begin{array}{l}0.85^{\mathrm{a}} \\
(4.09)\end{array}$ & $\begin{array}{l}0.85^{\mathrm{a}} \\
(4.11)\end{array}$ & $\begin{array}{l}0.85^{\mathrm{b}} \\
(2.54)\end{array}$ & $\begin{array}{l}0.88^{\mathrm{c}} \\
(1.88)\end{array}$ & $\begin{array}{l}0.85^{\mathrm{a}} \\
(4.03)\end{array}$ \\
\hline $\begin{array}{l}\text { Real GDP growth of trading partner } \\
\text { it-1 } x \text { WTO }\end{array}$ & $\begin{array}{l}0.96^{\mathrm{b}} \\
(1.98)\end{array}$ & $\begin{array}{l}0.97^{c} \\
(1.70)\end{array}$ & $\begin{array}{l}0.97^{\mathrm{c}} \\
(1.81)\end{array}$ & $\begin{array}{l}0.99 \\
(0.19)\end{array}$ & $\begin{array}{l}1.00 \\
(0.07)\end{array}$ & $\begin{array}{c}0.97 \\
(1.37)\end{array}$ \\
\hline [Test statistic] & {$[9.99]^{\mathrm{a}}$} & {$[10.64]^{\mathrm{a}}$} & {$[10.41]^{\mathrm{a}}$} & {$[6.00]^{\mathrm{b}}$} & {$[3.70]^{\mathrm{c}}$} & {$[10.90]^{a}$} \\
\hline $\begin{array}{l}\text { Import growth from trading partner } \\
\text { ijt-1 x GATT }\end{array}$ & $\begin{array}{c}0.89 \\
(1.13)\end{array}$ & $\begin{array}{c}0.89 \\
(1.11)\end{array}$ & $\begin{array}{c}0.89 \\
(1.13)\end{array}$ & $\begin{array}{c}0.81 \\
(1.39)\end{array}$ & $\begin{array}{c}0.73 \\
(1.57)\end{array}$ & $\begin{array}{c}0.87 \\
(1.28)\end{array}$ \\
\hline $\begin{array}{l}\text { Import growth from trading partner } \\
\text { ijt-1 } \times \text { WTO }\end{array}$ & $\begin{array}{c}1.00 \\
(1.04)\end{array}$ & $\begin{array}{l}1.00 \\
(1.02)\end{array}$ & $\begin{array}{c}1.00 \\
(1.06)\end{array}$ & $\begin{array}{c}1.21 \\
(0.79)\end{array}$ & $\begin{array}{c}1.18 \\
(0.65)\end{array}$ & $\begin{array}{l}1.00 \\
(1.04)\end{array}$ \\
\hline [Test statistic] & [1.28] & {$[1.25]$} & [1.28] & {$[2.01]$} & {$[2.22]$} & [1.65] \\
\hline WTO & $\begin{array}{l}1.84^{\mathrm{c}} \\
(1.67)\end{array}$ & $\begin{array}{c}1.92^{\mathrm{c}} \\
(1.80)\end{array}$ & $\begin{array}{l}1.83^{\mathrm{c}} \\
(1.66)\end{array}$ & $\begin{array}{l}0.98 \\
(0.03)\end{array}$ & $\begin{array}{l}3.78^{\mathrm{b}} \\
(2.32)\end{array}$ & $\begin{array}{l}2.39^{b} \\
(2.38)\end{array}$ \\
\hline $\begin{array}{l}\text { Change in the share of imported } \\
\text { products under WTO discipline } j t-1 \\
\mathrm{x} \text { WTO }\end{array}$ & -- & $\begin{array}{l}1.04^{\mathrm{a}} \\
(3.24)\end{array}$ & $\begin{array}{l}1.03^{\mathrm{a}} \\
(2.71)\end{array}$ & $\begin{array}{l}1.07^{\mathrm{a}} \\
(2.94)\end{array}$ & $\begin{array}{l}1.06^{\mathrm{a}} \\
(2.61)\end{array}$ & $\begin{array}{c}1.03 \\
(1.60)\end{array}$ \\
\hline Time trend included & yes & yes & yes & yes & yes & yes \\
\hline $\begin{array}{l}\text { Import and exporter combined fixed } \\
\text { effects }\end{array}$ & yes & yes & yes & yes & yes & yes \\
\hline Observations & 2,777 & 2,777 & 2,777 & 1,633 & 1,633 & 1,863 \\
\hline
\end{tabular}

Notes: Policy-imposing countries $j$ vis-à-vis one of the trading partners $i$ (listed in the Appendix) over 1989-2010. Explanatory variables are each lagged one year (at $t-1)$. The domestic economy variable is defined as the lagged change in domestic real GDP growth in all columns except (4) in which it is defined as the lagged change in the domestic unemployment rate. Incidence Rate Ratios (IRRs) are reported in lieu of coefficient estimates, with $t$ statistics in parentheses. Each model includes a constant term whose estimates are suppressed. Superscripts a, $b$, and c indicate statistical significance at the 1 percent, 5 percent, and 10 percent levels, respectively. The notation $x$ GATT indicates that a dummy for the GATT years (1994 and earlier) is turned on, whereas $x$ WTO indicates that a dummy for the WTO years (1995-2010) is turned on. 
Figure 1: Changes to WTO Disciplines over Emerging Economy Applied Tariffs, 1996-2010

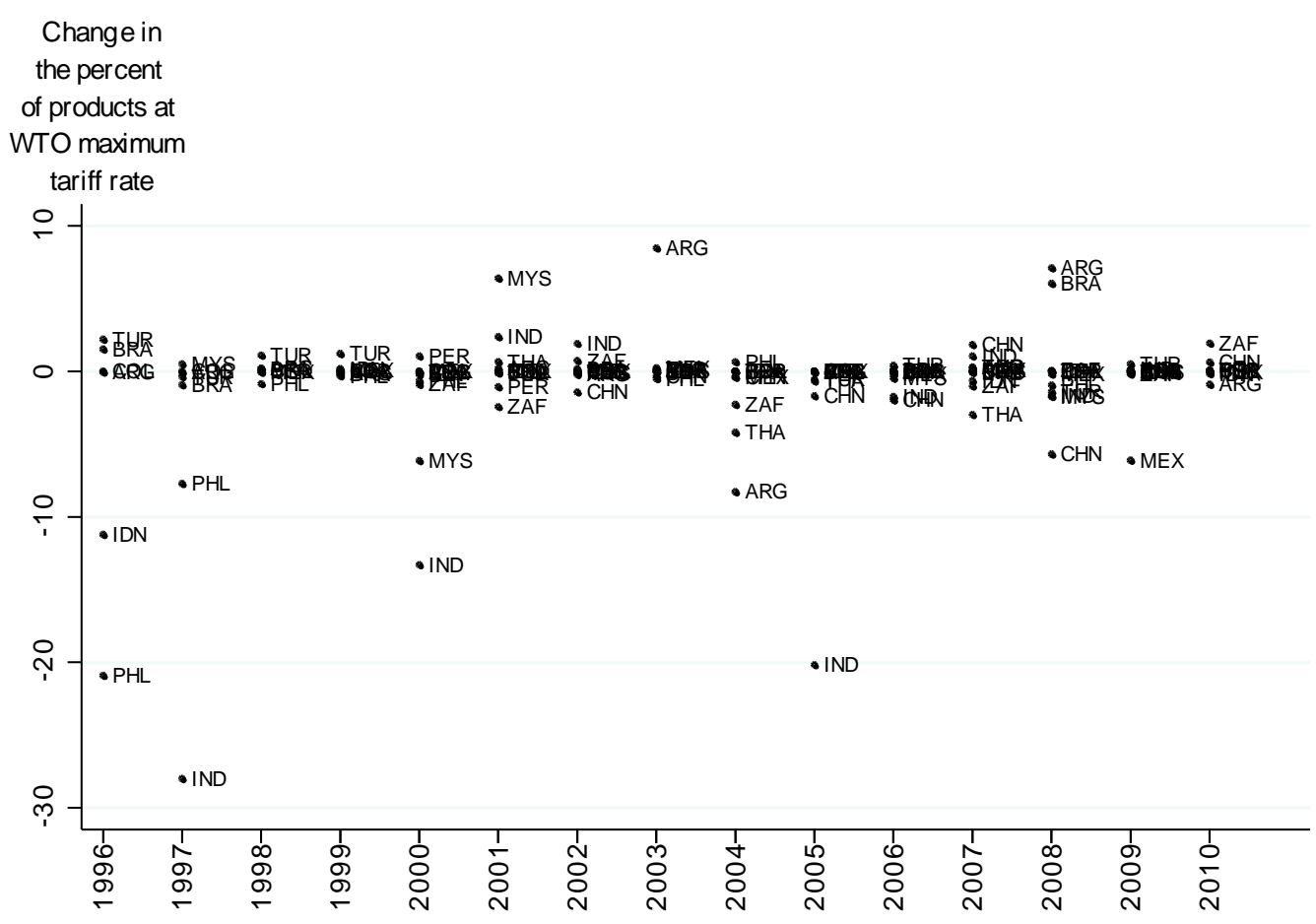

Notes: Constructed by the authors from WTO (2011) and WITS. For scaling purposes, one observation for Thailand of -60 percent in 2000 is omitted from the figure; this observation is included in the empirical analysis. 
Figure 2: Temporary Trade Barrier Responsiveness to Macroeconomic Shocks, 1995-2010

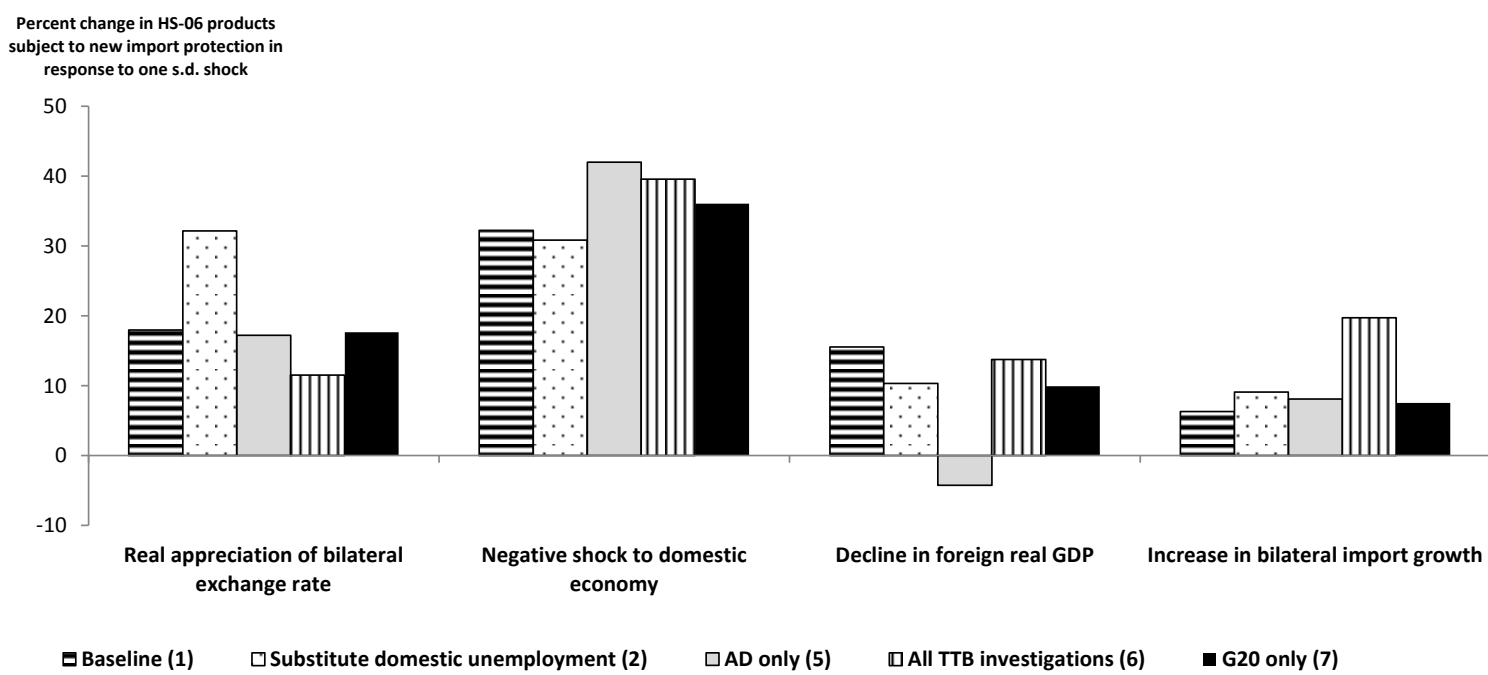

Notes: Percent change in HS-06 products subject to new import protection per year per trading partner. Based on Table 3 model estimates with specifications given in parentheses, and a one standard deviation change in each explanatory variable away from the sample mean, holding all other variables constant. Models (1), (5), (6), and (7) are estimated using the lagged domestic real GDP growth rate as the negative shock to the domestic economy, whereas as model (2) is estimated using the lagged change in the level of the domestic unemployment rate. 
Figure 3: TTB Import Protection and Macroeconomic Shocks during the GATT versus WTO Periods

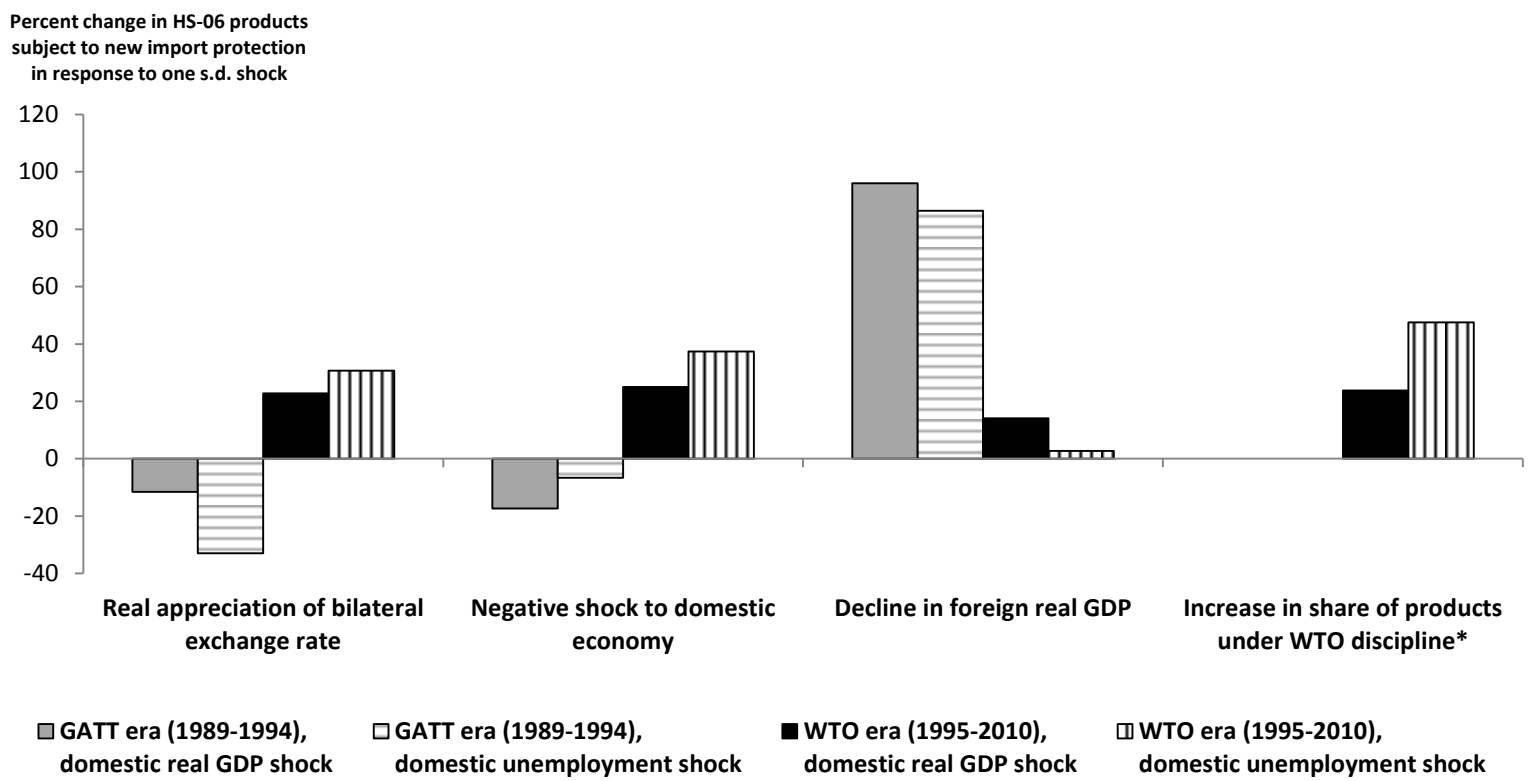

Notes: Percent increase in HS-06 products subject to new import protection per year per trading partner, based on Table 4 model estimates of specifications (2) and (4). In each case the approach is to use a one standard deviation change in each explanatory variable away from the sample mean, holding all other variables constant, where the mean and subsample are defined on the relevant subsample of years. *Variable only relevant for the WTO period. 